\title{
SETTLEMENT ASPECTS OF ECONOMIC DEVELOPMENT IN KHARKIV REGION
}

\author{
'Pavlo VIRCHENKO, ${ }^{2}$ Kateryna KRAVCHENKO \\ 1,2 V. N. Karazin Kharkiv National University \\ ${ }^{2}$ kate4465@gmail.com
}

\begin{abstract}
The formation of regional settlement system is defined by the historical process of settling. Kharkiv Region has been populated for a long time both voluntarily and forcibly, which led to development of a special settlement system characterized by a strong monocentric agglomeration and significant development disproportion from the centre to the periphery. Scientific literature has no unified clear concept of the territorial economic development. We propose to understand this term as the complex of settlement processes and the development of interchange in the system "society-nature" in the particular region. Settlement processes we consider to be one among the most important aspects of the territorial economic development. The peculiarities of settlement system in Kharkiv Region are defined by the following factors: profitable physiographical location, favourable climatic conditions, forcible settling of the region, rapid economic development, and directly the proximity to the city of Kharkiv. Modern settlement system in Kharkiv Region is characterized by a large concentration of population in the central part and near the regional capital. Cities play an important role of the population placement in Kharkiv Region. Consequently, the problem of spatial imbalance in the regional development requires the implementation of regional policies aimed an economic development of industrial centres, emphasis on social infrastructure development in the peripheral regions, and development of villages and rural settlement system.

Key words: economic development of the region, settlement of population, settlement processes, agricultural development, industrial development, development imbalance, regional policy.
\end{abstract}

DOI: http://dx.doi.org/10.17721/2413-7154/2016.75.41-45

UDC: 911.3

\section{РОЗСЕЛЕНСЬКІ АСПЕКТИ ГОСПОДАРСЬКОГО ОСВОЄННЯ ТЕРИТОРІЇ ХАРКІВСЬКОЇ ОБЛАСТІ}

\author{
'ПавЛо ВІРЧЕНКО, ${ }^{2}$ КатерИна КРАВЧЕНКО \\ 1,2Харківський начіональний університет імені В. Н. Каразіна \\ ${ }^{2}$ kate4465@gmail.com
}

\begin{abstract}
Анотація: Формування системи поселень обумовлюється історичним процесом заселення регіону. Харківська область заселялась протягом тривалого часу як добровільно, такі примусово, завдяки чому сформувалась особлива система розселення з потужною моноцентричною агломерацією, значною диспропорцією розвитку «центр-периферія». В науковій літературі не існує чіткого поняття господарського освоєння території, тому під господарським освоєнням території пропонуємо розуміти сукупність розселенських процесів та формування взаємообміну в системі «суспільство - природа» на певній території. Одним з найважливіших аспектів господарського освоєння території $\epsilon$ заселенсько-розселенські процеси. Основними чинниками заселення Харківського регіону є: вигідне фізико-географічне положення, сприятливі природно-кліматичні умови, примусове заселення території, стрімкий економічний розвиток регіонута безпосередньо м. Харків. Щодо основних сучасних особливостей розселення населення Харківської області можна зазначити, що значною $\epsilon$ концентрація населення в центральних районах області та розміщення населення поблизу обласного центру. Важливу роль у розселенні населення Харківської області відіграють міста. Отже, для вирішення проблеми скошеності розвитку у регіоні необхідною є реалізація регіональної політики, спрямованої на економічний розвитокпромисловихцентрів, акцентуацію на розвитку соціальної інфраструктури периферійних регіонів, розвиток сіл та сільських систем розселення.
\end{abstract}

Ключові слова: господарське освоєння регіону, розселення населення, заселенсько-розселенські процеси, сільськогосподарське освоєння, промислове освоєння, диспропорція розвитку, регіональна політика.

DOI: http://dx.doi.org/10.17721/2413-7154/2016.75.41-45

удк: 911.3

Актуальність. Історико-географічні особливості господарського освоєння території $€$ передумовою для дослідження сучасного стану його господарства та встановлення пріоритетів її подальшого розвитку. Важливим аспектом господарського освоєння регіону є розселенсько-заселенські процеси.

Формування системи поселень обумовлюється історичним процесом заселення регіону та роз-

(C) П. Вірченко, К. Кравченко селенням населення по його території. Харківська область є однією з економічно розвинених областей України, тут зосереджений потужний природноресурсний потенціал, історично сформовані трудові ресурси, потужні ВНЗ тощо. Область заселялась протягом тривалого часу як добровільно, так i примусово, завдяки чому сформувалась особлива система розселення 3 потужною моноцентричною агломерацією, значною диспропорцією розвитку «центр-периферія». 
Аналіз попередніх досліджень. Окремі аспекти господарського освоєння Харківської області розкриваються в працях таких вітчизняних вчених, як А. П. Голіков [3], Л. М. Нємець [8-10], К. Ю. Сегіда [13] В. О. Пірко [12] та інші, проте існуючі досліди мають фрагментарний характер.

Виклад основного матеріалу. Процес господарського освоєння Харківської області привертав увагу науковців в різні часи, а особливо в контексті аналізу соціально-економічних наслідків примусової заселенської політики в регіоні [2]. В науковій літературі не існує чіткого поняття господарського освоєння території, тому під господарським освоєнням території пропонуємо розуміти сукупність розселенських процесів та формування взаємообміну в системі «суспільство - природа» на певній території [10]. Засобом господарського освоєння виступає працяя, а сам процес має три рівні - розселенського, сільськогосподарського та промислового освоєння (рис. 1).

Одним 3 найважливіших аспектів господарського освоєння території $\epsilon$ заселенсько-розселенські процеси, які пропонуємо розуміти як міграційне явище історичного характеру, яке проявляється у переміщенні населення на відповідну територію та розселення по ній з метою постійного проживання та здійснення господарської діяльності.

Розуміння історико-географічних процесів формування розселення дає можливість не тільки розрізняти системи розселення за часом ïx формування, але й встановити етапи їх трансформацій та ускладнень [5, 8]. Виходячи 3 різноманітності часових періодів, які виявлено при ретроспективному аналізі досліджень особливостей процесів заселення території Харківської області доцільно зупинитися на визначенні їхніх специфічних хронологічних меж:

I. Період первинного освоєння території (X тис. до. н.е. - VI ст.).

II. Період осіло-розселенського освоєння території (VI - XVII ст.).

III. Козацько-військовий переселенський період (XVIII - XIX ст.).

IV. Період радянської індустріалізації (XX ст.: 1919-1991 рр.)

V. Період незалежності України (XXI ст.: 1991р. - дотепер).

Розселення населення $є$ закономірним процесом і відбувається під впливом певних чинників, які обумовлюють його особливості. В процесі заселення Харківської області спостерігались три великі хвилі міграції: первинне заселення регіону, примусове заселення на початку XVII ст., трудові міграції на початку XX ст.

Основними факторами заселення Харківського регіону виступали $[3,8]$ :

1). Вигідне фізико-географічне положення регіону у центрі залюдненого континенту.

2). Сприятливі природно-кліматичні умови для господарської діяльності.

3). Забезпеченість регіону водними ресурсами.

4). Орографічні умови території - рівнинний рельєф.

5). Примусове заселення території для захисту кордонів Московії.

6). Надання пільг добровільним мігрантам у XVII ст.

Рівні господарського освосиня території.

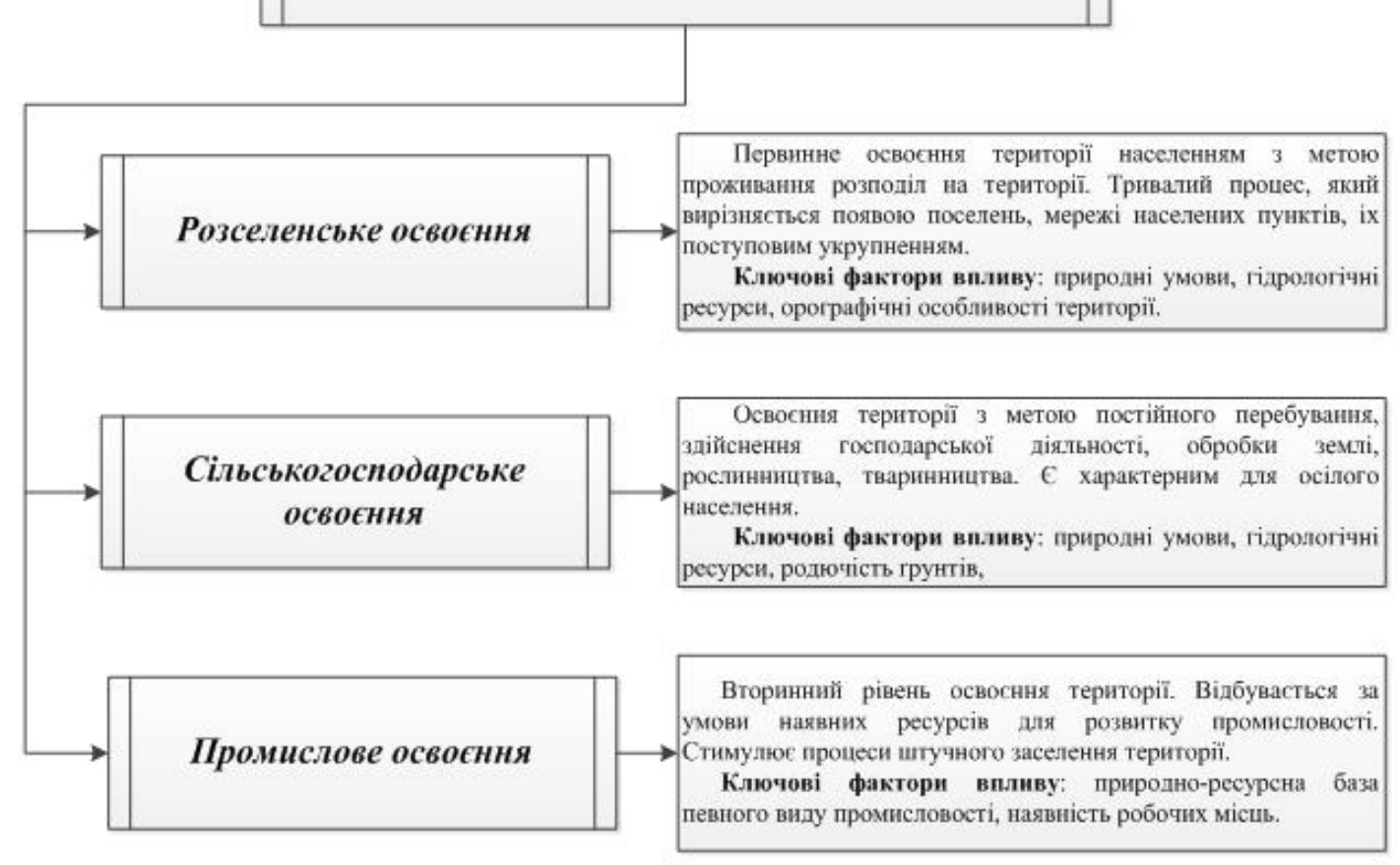

Рис. 1. Рівні господарського освоєння території (побудовано за даними $[2,6,8]$ ). 
7). Стрімкий економічний розвиток регіону та безпосередньо м. Харків. $\mathrm{XX}$ ст.

8). Економіко-політичні реформи уряду у XIX-

9). Вигідне транспортно-географічне положення регіону.

Дякуючи сприятливим природним умовам: рівнинній території, м’якому клімату, розгалуженій гідрографічній мережі та родючим грунтам Харківщина освоювалась швидко [1]. У часи господарського освоєння території було виявлено значну кількість горючих та неметалевих корисних копалин на території сучасної Харківської області, що 3 часом стало вагомим стимулом для трудових міграцій в регіон $[11,13]$. Під впливом розвитку промислового та сільськогосподарського виробництва (на первинних етапах розвитку сільського господарства, цукрової промисловості, а 3 часом паливноенергетичного комплексу) в регіоні сформувалось сприятливе виробничо-економічне середовище, яке зараз дозволяє регіону займати провідні позиції в Україні за рівнем економічного розвитку [3, 29]. Завдяки розвитку невиробничої сфери: освіти, охорони здоров'я, науки, мистецтва та потужній інфраструктурі Харківська область є прикладом сприятливого соціального та культурного середовища, яке позитивно вливає на формування та розвиток особистості. Проте, не можна сказати, що регіон розвивається комплексно, адже існує різка відмінність між розвитком центральних та периферійних районів області [8].

Отже, розселення населення $є$ показником рівня розвитку території, адже зазвичай населення концентрується у сприятливих для життя та господарської діяльності містах та районах [5].

Щодо основних сучасних особливостей розселення населення Харківської області можна зазначити, що значною $є$ концентрація населення в центральних районах області та розміщення населення поблизу обласного центру [14].

Населення Харківської області розміщене вкрай нерівномірно по іiї території. Середня густота розселення населення становить 87 осіб/км ${ }^{2} 3$ врахуванням великих міст та 32 особи/км² без їх врахування [15].

Найбільш густо заселеними $є$ центральні райони, близькі до м. Харків: Харківський, Дергачівський, Чугуївський, Зміївський та Балаклійський, що свідчить про значний економічний розвиток не тільки міста Харків, а і всієї Харківської агломерації [8].

Важливу роль у розселення населення Харківської області відіграють міста: наявність міста мільйонера - Харкова, яке є обласним центром, та інших міста із значною чисельністю та густотою населення - Зміїв, Чугуїв, Люботин, Ізюм та інші.

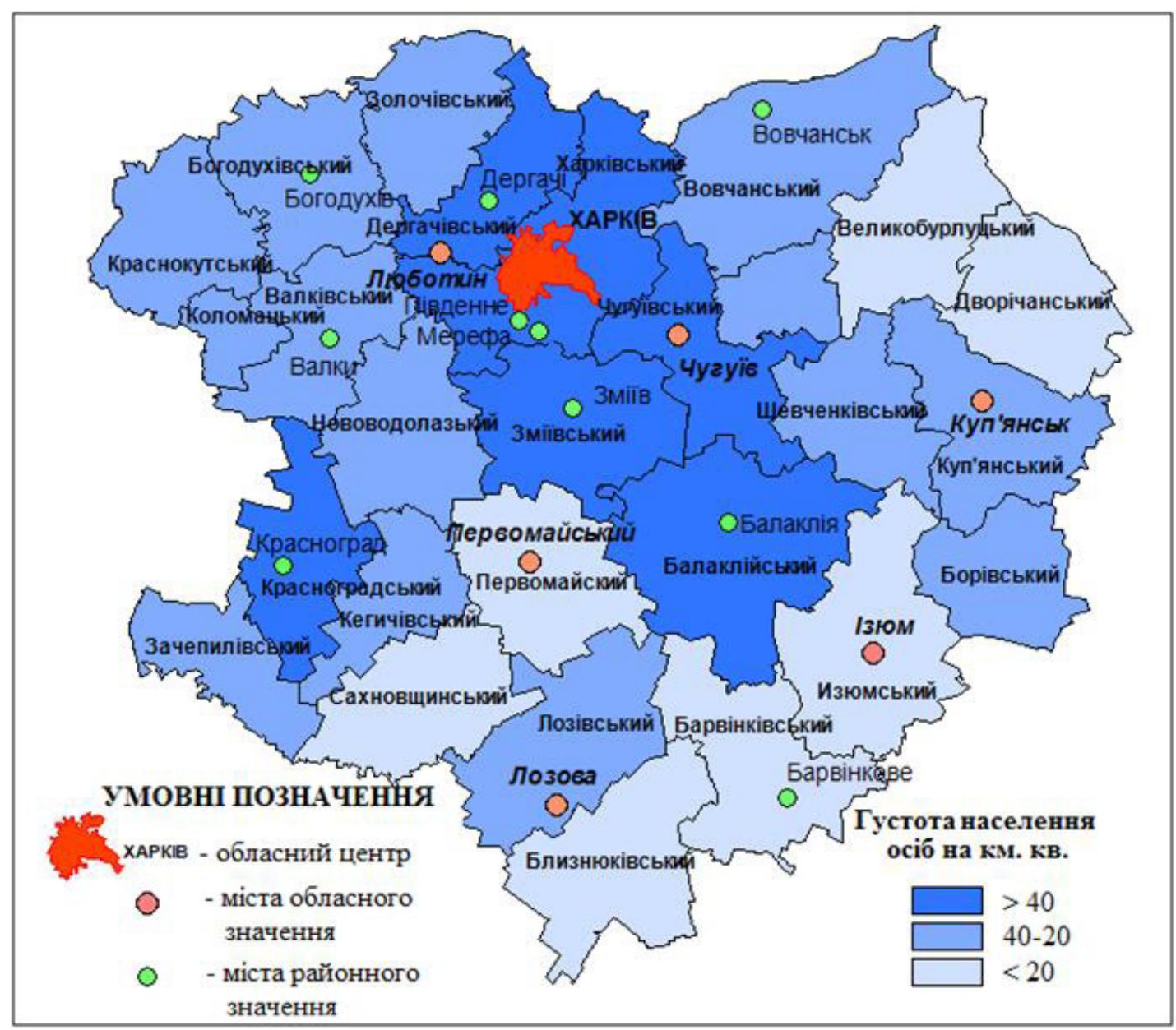

Рис. 2. Розселення населення Харківської області у 2014 р. (побудовано за даними [15]). 
Населення Харківщини сконцентроване в центрі області та поблизу обласного центру. Такий розподіл зумовлено рядом причин:

- наявністю значної кількості робочих місць;

- значним розвитком освіти та науки;

- економічним та соціальним розвиток території;

- наявністю та активним функціонуванням культурної сфери;

- забезпеченістю продовольчими запасами та їх різноманітністю [3].

Зазначені та ряд інших факторів обумовили тяжіння населення до обласного центру та його приміських територій. Для вирішення проблеми скошеності розвитку регіону необхідною є реалізація регіональної політики, спрямованої на:

- економічний розвиток міст, які у минулому були промисловими центрами, та зберегли свій ресурсний потенціал (Ізюм, Чугуїв), що передбачає модернізацію вже існуючих, але застарілих фондів підприємств, зайнятість за фахом для трудових ресурсів, які через закриття підприємств втратили роботу, або працевлаштувались не за професією, створення нових робочих місць для молодих спеціалістів, у селах - трудова зайнятість для безробітних, що дозволить прискорити розвиток агропромислового комплексу області.

- акцентуацію на розвитку соціальної інфраструктури периферійних регіонів області, невеликих містечок та сіл, що зробить їх привабливими не тільки для постійного проживання а і для розвитку різноманітних видів туризму у області (агротуризм, діловий туризм, тощо) [3];

- розвиток сіл та сільських систем розселення: залучення тимчасово безробітних трудових ресурсів у галузі сільського господарства шляхом фінансового стимулювання, що дозволить не тільки знизити рівень безробіття в області, а i розвинути перспективні галузі сільського господарства.

Для оптимізації мережі розселення населення у Харківській області необхідним є залучення інвестицій у перспективні галузі господарства, 3 урахуванням інвестиційних паспортів міст та районів.

Висновки. Характеристика первинного розселенського освоєння території та аналіз заселенсько-розселенських процесів у регіоні свідчать про те, що він має тривалу специфічну історію формування заселенсько-розселенської мережі, завдячуючи не тільки міграційним процесам, а й примусовому заселенню краю. Визначено, що сільськогосподарське освоєння території, завдяки сприятливим агрокліматичним умовам Харківської області довгий час відігравало провідну роль у освоєнні регіону. Промислове освоєння території переважно пов'язане 3 процесами індустріалізації. Харківська область вирізняється високим рівнем розвитку соціальної інфраструктури та освіти. На сучасному етапі еволюції особливості розселення населення значною мірою визначають рівень економічного розвитку районів області, тому нагальним завдання регіональної політики сьогодні є подолання цієї диспропорції.

Ефективна регіональна політика, спрямована на розвиток малих міст та депресивних територій сприятиме комплексному розвитку, як системи розселення Харківщини, так і господарства регіону в цілому.

\section{References:}

1. Bagalìj D. İ. İstoriâ Slobids'koï Ukraïni [The history of Sloboda Ukraine]. Kharkiv, 1993, 256 p. (In Ukrainian)

2. Brovčenko İ.Û. Zaselennâ ta gospodars'ke osvoênnâ pìvdenno-shìdnih stepìv Ukraïni v drugìj polovinì XVII protâgom XVIII st. [The settlement and economic development of the south-eastern steppes of Ukraine in the second half of the XVII century and during the XVIII century]. PhD Thesis. Kharkiv, 2004, 25 p. (In Ukrainian)

3. Džaman V. O. Do problemi ocìnûvannâ vplivu prirodno-resursnih možlivostej teritoriì na regìonal'nì osoblivostì rozselennâ [The problem of assessing the impact of territorial natural resource opportunities territory on the regional settlement features]. Ekonomichna ta Sotsialna Geografiya, 2001, Vol. 51, pp. 46-52. (In Ukrainian)

4. Golìkov A.P., Sidorenko A.L. Har'kovskaâ oblast': Priroda, naselenie, hozâjstvo [Kharkiv region: nature, population, economy]. Kharkiv, 2011, 288 p. (In Russian)

5. Gudzelâk İ. İ. Geografiâ naselennâ: Navčal'nij posibnik [Geography of Population: Textbook], L'vìv, 2008, 232 p. (In Ukrainian)

6. Kaufman A. A. Pereselenie i kolonizaciâ [The resettlement and colonization]. Saint Petersburg, 1905, 81 p. (In Russian).

7. Krul' V. P. Retrospektivna geografiâ poselen' Zahidnoï Ukraïni [Retrospective geography of settlements in Western Ukraine]. Chernivtsi, 2004, 382 p. (In Ukrainian).

8. Nêmec' L. M. Geografiâ naselennâ: ukraïns'ko-rosijs'ko-anglìjs'kij slovnik termìnìv ta ponât' [Geography of Population: Ukrainian-Russian-English dictionary of terms and concepts]. Kharkìv, 2011, 144 p.

9. Nêmec' L. M. Vìrčenko P. A., Kravčenko K. O. Suspil'no-geografičnì aspekti gospodars'kogo osvoênnâ teritoriï (na prikladì staropromislovogo regìnu) [Territory settlement from the standpoint of human geography (the case of an old industrial region)]. Časopis social'no-ekonomičnoï geografï: mižregional'nij zbirnik naukovih prac' [Journal of Social and Economic Geography], 2014, Vol. 17 (2), pp. 66-71. (In Ukrainian).

10. Nêmec' L. M., Segìda K. U., Nêmec' K. A. Demografičnij rozvitok Harkivs'kogo regìonu [Demographic development in Kharkiv region]. Kharkiv, 2012, 200 p. (In Ukrainian). 
11. Nêmec' L. M., Segìda K. Û., Nêmec' K. A. Retrospektivnij analìz zaselennâ Harkìvs'kogo regìonu [Settlement in Kharkiv Region: retrospective analysis]. Časopis social'no-ekonomičnoï geografï̈ [Journal of Social and Economic Geography], 2008, Vol. 5(2), pp. 171-177. (In Ukrainian).

12. Pìrko V. O. Zaselennâ ì gospodars'ke osvoênnâ Stepovoï Ukrä̈ni v XVI-XVIII st. [The settlement and economic development of Steppe Ukraine in XVI-XVIII centuries]. Donetsk, 2004, 224 p. (In Ukrainian).

13. Segìda K. U. Rozselennâ naselennâ Harkìvs'koï oblastì: teritorìal'nij aspekt [Settling in Kharkiv region: territorial aspect]. Visnik Harkìvs'kogo nacional'nogo unìversitetu ìmenì V. N. Karazina. Ser : Geologîa - Geografîa Ekologiâ [Journal of Kharkiv National University. Series: Geology - Geography - Ecology], 2013, Vol. 38, pp. 165-169. (In Ukrainian).

14. Segìda K.Û. Metodičnì osnovi analìzu rozselennâ naselennâ region [Methodological basis of analysis of population settlement region]. Problemi bezperervnoï geografičnoï osviti i kartografï̈ [Problems of continuous education and geographical mapping], 2013, Vol. 18, pp. 150-155. (In Ukrainian).

15. The official website of the State Statistics Service in Kharkiv Region. Access mode: http://www.kh.ukrstat. gov.ua. 